\title{
Empowerment of Smart Human Resources by Enhanced Innovation (Manager's Perspective at Creative Industry)
}

\author{
Sevenpri Candra ${ }^{1}$, Natalya $^{2}$, Melianie $^{3}$, Diah Wulansari $^{4}$ \\ Management Department, BINUS Business School Undergraduate Program, \\ Bina Nusantara University, Jakarta, Indonesia $11480^{1}$ \\ Management Department, BINUS Online Learning, Bina Nusantara University, \\ Jakarta, Indonesia $11480^{2,3,4}$ \\ $\left\{\right.$ seven@binus.ac.id $\left.{ }^{1}\right\}$
}

\begin{abstract}
The growth of creative industries rely on the creativity and ability of employees, that make the approach of human resources is currently based on human capital. Innovations made can be formed through proper human resource practices and strong human capital. This study aims to empowerment smart human resources and determine the effect of human resource practice on innovation with human capital as an intervening variable. The method used for this research is Structural Equation Modeling (SEM) with WarpPLS 6.0 software. The data used for the study were 97 respondents from distributing questionnaires with Online Survey. The results of this study indicate that human resource practice influences innovation through human capital. The stronger the human resource practice, the human capital owned by the company will be more competent so that it can produce better innovation.
\end{abstract}

Keywords: Human Resource Practices, Human Capital, Innovation, Recruitment and Selection, Training, Development

\section{Introduction}

The development of Industry 4.0 brings fundamental changes to various global life settings, where creativity and innovation occur in this global life. And that gave birth to the Creative Economy. The creative economy itself is widely known since the emergence of the book The Creative Economy: How People Make Money from Ideas written by John Howkins. The term creative economy raised Howkins when he saw a new economic wave that hit the United States. The new economic wave is characterized by economic activities based on ideas, ideas and creativity. Creative economy can be said as an economic concept in the new economic era that intensifies information and creativity by relying on ideas and stock of knowledge from Human Resources (HR) as the main production factor in its economic activities. The growth of the creative industry is developing very rapidly in the world along with the rapid development of technology from year to year as well. UNCTAD explained that 
the global value of creative products and services in the world in 2017 reached $\$ 509$ billion, a drastic increase compared to 2012 which only reached $\$ 208$ billion [1].

The progress of the creative industry can occur because in general, the creative economy is an industry that utilizes creativity, talent, and the ability of individuals to create prosperity and employment. Innovation is one of the capabilities that are present because of the talent or habits that make the creative economy sector an industry that comes from renewable and dynamic resources [2]. The growth of creative industries in the world is also followed by positive trends in the growth of creative industries in Indonesia as well. In 2016, the creative economy created GDP was 922.59 trillion Rupiah, which is $7.44 \%$ of total GDP [2]. Based on various data compiled from the Creative Economy World Conference (2018), the creative industry sector in Indonesia has contributed gross domestic product of 952 trillion Rupiah, equivalent to 7.3 percent of Indonesia's total GDP over the past 3 years [3]. In terms of workers, the creative industry sector contributes employment to 15.9 million people, equivalent to 13.9 percent of total employment in Indonesia. That means there are 14 out of 100 people in Indonesia who work in the creative industries. In terms of economic growth, the creative economy can contribute $7.57 \%$ and absorb as many as 18.1 million workers in 2016 [2]. Based on the results of the distribution of creative economy ventures, there were $8,203,806$ creative economy business enterprises in Indonesia with the most in the city of Jakarta with $21.73 \%$ of all creative economy business enterprises in Indonesia [2].

The development of the creative industry sector is making the competition map among companies more stringent, this makes companies need to create new innovations to form a competitive advantage in the company so that it makes it one step ahead compared to similar companies engaged in the creative industry sector. The problem faced by this creative industry is on human resources, because qualified human resources especially in the creative field are very limited in Indonesia and often it takes a hard effort from companies engaged in the creative industry sector to form a solid team. Creative industries are demanded to continue to innovate in order to be able to compete and increase the added value of their products so that they contribute significantly to the national economy.

Innovation can arise because of human capital. Human capital is very important for companies, especially companies engaged in the creative industry, because human capital is crucial for the life and death of companies, such as marketing positions and creative parts of companies that have a crucial portion. The existence of these resources will make the company able to innovate because its human resources are quite competent and able to think about innovation that must be done to be able to compete with other companies [4] who conduct research on the influence of human capital towards innovation carried out by small companies found that the better the human capital of a company, the innovation will increase, this shows the positive influence of human capital on innovation. Research by [5] also shows the same results that human capital has a positive effect on innovation because human capital is formed from the sharing of knowledge owned by employees owned by the company will encourage companies to more quickly innovate.

Ref [6] that to get strong human capital, companies need to implement a strong human resource practice strategy that is by paying attention to the recruitment / selection process and training / development process to form a solid team that is solid contains the best figures to increase human capital. Ref [7] states that with a strong human resource practice, a company will have employees who are able to make their own decisions, think creatively and innovatively and be able to increase overall company innovation.

The problems faced by creative industry companies are that creative industry companies depend very much on their human resources to produce innovative, unique and creative 
products that support their performance. Based on existing data illustrates that currently creative industry companies are getting serious in doing good human resource practices to form strong human capital and ultimately to improve innovation in companies, so it needs to be investigated how to increase human capital and innovation in creative industry companies in Jakarta.

\section{Literature Review}

\subsection{Innovation}

Innovation is a new idea that is applied to initiate or improve a product or process and service [5], [8]. Innovation is the discovery / expression of ideas, ways, concepts and objects that are perceived as new [9]. Innovation is the change of existing knowledge or new knowledge into new products or change products, processes, and services that intend to create new value to customers and provide financial improvements to innovation makers. According to [10] innovation can be seen from two sides, namely product innovation and process innovation. Product innovation is innovation that is carried out exclusively on products produced to create new products. An organization can be said to carry out product innovation if the Company is always able to introduce its new products every year; Products released by companies are pioneers in their fields; New products launched can be superior to competitors. Meanwhile, Process innovation is an innovation carried out in the production process to make the production process more effective and efficient. This can be seen in the habit of the Company often making changes in the work process; The company is a pioneer in terms of changing the work process more quickly; The company wants to spend $\mathrm{RnD}$ funds to get a more efficient work process.

\subsection{Human Capital}

Human capital arises as a result of the shift in the role of human resources in the organization from being a burden to an asset / capital. The concept of human capital initiates the added value that employees (humans) can give to the organization where they work. Chatzkel states that human capital is the differentiating factor and the actual basis of an organization's competitive advantage [11]. The concept of human capital should be seen as a bridge that defines the relationship between human resource management practices and business performance. Based on [12], human capital can be seen from three aspects, namely intellectual capital, social capital and organizational capital. Intellectual capital is capital that comes from the collection of knowledge and expertise possessed by employees. While social capital is capital owned by a company that comes from the ability of interaction from members of the organization. And Organizational capital is capital in the form of a strong organizational pillar that will not change even if the people in the organization change.

\subsection{Human Resource Practices}

Human Resource Practices (HRP) is an important matter to be considered by the company, this is because it will relate to the desire of employees to leave (intention to leave). HRP includes things such as uncompetitive compensation, high stress, working conditions, monotony, poor supervision, poor communication and other organizational practices [13]. HR 
Management as a process of HR practices in carrying out its functions will distribute workers in various fields of the organization according to their needs. This shows that human resource management has links with other fields of management in the organization to achieve effective work results [14]. Human resource management activities must be carried out through the right process, so that all HR management activities can run on its path with the aim of facilitating its management, while achieving the goals is also easy to achieve. The management process is known as human resource management functions. According to [13] indicators of human resource practice can be measured from several things, namely: Work that is charged by the company is in accordance with employee competencies; The ability of employees to work well with their colleagues; The company always recruits the right employees; The training provided is always in accordance with the needs of the job; The company has the right career track for every employee; The company gives a fair assessment to employees; Compensation provided by companies always matches work performance.

\section{Research Method}

The scope of this research is only focuses on examining the creative industries in Jakarta. Based on the results of the distribution of creative economy ventures, there were $8,203,806$ creative economy business enterprises in Indonesia with the most in the city of Jakarta with $21.73 \%$ of all creative economy business enterprises in Indonesia [2]. The sampling technique used in this study was using purposive sampling technique, or sampling with certain criteria [15]. The sample criteria of this study were managers or employees at the level of managers in creative economy companies in the city of Jakarta. Data collection techniques in this study are using questionnaire media whose contents are about the factors that influence innovation. The score in the questionnaire uses a Likert scale with a scale of 1-5. Whereas for statistical analysis will use Structural Equation Modeling [16]-[18].

\section{Result and Discussion}

The data collection process was carried out with an online questionnaire sent to managers working in the creative industries. From the questionnaire sent directly to the managers, 97 questionnaires were returned and filled out completely so that all answers from respondents could be used for further analysis. The demographic characteristics of the respondents can be seen in Table 1.

\begin{tabular}{|c|c|c|c|c|c|}
\hline Profile Respondents & Frequency & Percentage & Profile Respondents & Frequency & Percentage \\
\hline Age & & & Managerial Level & & \\
\hline Under 24 & 18 & $19 \%$ & Top Manager & 24 & $25 \%$ \\
\hline $25-30$ & 32 & $33 \%$ & Middle Manager & 40 & $41 \%$ \\
\hline $31-35$ & 29 & $30 \%$ & Low Manager & 33 & $34 \%$ \\
\hline $36-41$ & 15 & $15 \%$ & Type of Creative Industries & & \\
\hline Above 42 & 3 & $3 \%$ & Architecture \& Interior Design & 4 & $4 \%$ \\
\hline Education & & & Product Design \& Photography & 6 & $6 \%$ \\
\hline High School & 22 & $23 \%$ & Digital Agency & 48 & $50 \%$ \\
\hline Diploma & 7 & $7 \%$ & Fashion & 5 & $5 \%$ \\
\hline Undergraduate & 61 & $63 \%$ & Film, Animation \& Video & 2 & $2 \%$ \\
\hline Master's degree & 7 & $7 \%$ & Financial & 2 & $2 \%$ \\
\hline Working Life (in year) & & & Food \& Beverage & 12 & $13 \%$ \\
\hline Under 6 & 51 & $53 \%$ & Logistic & 1 & $1 \%$ \\
\hline $6-11$ & 29 & $30 \%$ & Marketplace & 5 & $5 \%$ \\
\hline $12-17$ & 11 & $11 \%$ & Music & 4 & $4 \%$ \\
\hline
\end{tabular}




\begin{tabular}{lccccc}
\hline Profile Respondents & Frequency & Percentage & Profile Respondents & Frequency & Percentage \\
\hline $18-22$ & 4 & $4 \%$ & OTT Service & 1 & $1 \%$ \\
Above 23 & 2 & $2 \%$ & Education & 2 & $2 \%$ \\
& & & Tour \& Travel & 3 & $3 \%$ \\
& & & Software Engineering & 1 & $1 \%$ \\
\hline
\end{tabular}

Based on statistic descriptive by mean value, as seen on Table 2. we can conclude that: Human resource practice in the creative industries is included in the high category. This means that the work that is charged by the company is in accordance with employee competencies, besides that employees are able to work well with colleagues. The company has recruited employees appropriately, training has also been according to ability so as to provide an appropriate career track. The existence of a fair assessment of the work by the company makes the compensation given accordingly. Human capital in the creative industry is included in the high category. This shows that employees have skills that are not possessed by other employees, their level of knowledge is also in accordance with competencies, able to share the knowledge they have with colleagues because their knowledge is an asset. Employees also always follow the company SOP because they feel that the company culture is in accordance with personality. Innovation in the creative industry is in the high category. This shows that the company is able to introduce new products every year that are pioneers in their fields and are superior to competitors. Companies often make changes in the work process so that it becomes faster, and want to spend $\mathrm{RnD}$ funds to get a more efficient work process.

Table 2. Mean Results

\begin{tabular}{lll}
\hline Variables & Mean & Category \\
\hline Human resource practice & 3,82 & High \\
Human capital & 3,99 & High \\
Innovation & 3,60 & High \\
\hline
\end{tabular}

In this study, researchers used the Structural Equation Modeling (SEM) analysis method. This method has two evaluation stages, namely evaluation of the measurement model and evaluation of the structural model. Evaluation of measurement models is an evaluation that determines the specification of the relationship between latent variables and the indicators that are in them. In evaluating the measurement model, a validity test will be done using convergent validity and discriminant validity of the indicator, and the reliability test is measured by composite reliability and Cronbach alpha [19]. Based on software calculations by Warppls all the processes are meet all the requirements. And for the hypothesis testing can be analyzed from $\mathrm{p}$-values and path coefficients, where the results as seen in Table 3.

Table 3. Path Coefficients and P-Value results

\begin{tabular}{lccc}
\hline \multicolumn{1}{c}{ Hypothesis } & p-value & Path Coefficients & Decisions \\
\hline Human Resource Practices $\rightarrow$ Human Capital & $<0.001$ & 0.580 & Accepted \\
Human Resource Practices $\rightarrow$ Innovation & $<0.001$ & 0.477 & Accepted \\
Human Capital $\rightarrow$ Innovation & $<0.001$ & 0.314 & Accepted \\
\hline
\end{tabular}

The highest survey results from Human Resource Practice, stated that the majority of respondents felt able to have good cooperation with coworkers and felt the work assigned by the company was in accordance with their competencies. As for Human Resource Capital, the results of the survey stated that they always follow the company's work procedures and feel able to share the knowledge they have with their coworkers. For Innovation, the highest survey results said they felt the new product launched was superior to its competitors, and felt 
the products released by the company were pioneers in their fields. The implication of the results of this study is that providing jobs that are in accordance with the competencies of employees will enable employees to use skills not possessed by other employees to work more effectively to support company innovation. In addition, by using the abilities that are only owned by the employee, the employee also feels able to share his experience and work better with other employees. The use of this unique ability of employees will create a strong corporate culture to form a company product that is a pioneer in their field so that they are able to be superior to competitors because they have faster work processes and support from $\mathrm{RnD}$ funds to get more effective work processes.

The results of this study are also supported by research from [6] stating that to get strong human capital, companies need to implement a strong human resource practice strategy that is by paying attention to the recruitment / selection process and the training / development process to form a team solid which contains the best figures to increase its human capital. Because in the face of competition today the company must have strong resources. The resources needed to run a company cannot be seen as a stand-alone part, but must be seen as a formidable entity that forms a synergy so that in this case the role of human resources is crucial [14]. The results of the study indicate that the existence of an appropriate human resource practice that is by empowering the ability of various employees to become an asset that can strengthen the company, so that human capital in the company also increases. This is done because in the creative industry, human labor is an irreplaceable asset.

Ref [20] states that strong human resource practices will make employees able to make decisions, so that management does not need to make decisions that are implementation, but only make strategic decisions. has a positive influence on innovation. Ref [7] states that with strong human resource practices, a company will have employees who are able to make their own decisions, think creatively and innovatively and be able to increase the company's overall innovation. The results of the study stated that with the better human resource practice, the company will encourage employees to think creatively and innovatively to create breakthroughs for the company so that it can increase innovation.

Human capital is a role of HR characteristics that is determined by the knowledge possessed that is used to create value for the organization [5]. Ref [12] states that employees who are the company's resources are the drivers of a company that has knowledge that can create added value for the company. The results of the study stated that the role of human resources in companies in the creative industry is very important because the existing human resources will shape the entire process of product creation, so that the innovation formed is due to the role of human resources.

\section{Conclusions}

The results of this study confirm the results of the study [6], [7], [11], [14] which states that human resource practice influences human capital. The development of good human resource practices will form a pool of employees who, when properly nurtured, will become a force or capital for the company. This capital is capital in the form of humans where companies invest time, money and knowledge to form employees into a pillar of the company so that in getting strong human capital, companies need to implement a strong human resource practice strategy that is by paying attention to the recruitment / selection process and the training process / development to form a solid team that contains the best figures to increase its human capital. 
The results of this study confirm the results of the study [7], [10], [13], [20] which states that human resource practice influences innovation. With good human resource practices, the company will have good employee resources and be able to do better innovation practices because employees have competent knowledge, and because there is a company's effort to direct the selection and recruitment process and prioritize training and development to form employees who are able to innovate in accordance with the company's vision and mission. The results of this study confirm [4], [5], [21] which states that human capital influences innovation. The formation of a strong human capital that contains employees who are "the right man on the right place with great mind", then a company has the basic capital in carrying out its innovation. The existence of a strong human capital in the company will make the company have more resources to use. The existence of these resources will make the company capable of innovation because its human resources are quite competent and able to think about innovation that must be done to be able to compete with other companies.

Creative industry companies need to provide compensation in accordance with the achievements of employees to optimize employee performance. In addition, the assessment of work performance itself needs to be done fairly to avoid a decrease in employee motivation. Companies engaged in the creative industry also need to form a culture that is in accordance with the personality of employees and look for employees who are willing to integrate with the values of the company culture. Companies need to always continuously upgrade their systems or work processes by accommodating the latest technology, for example, cloud based working space that allows employees to work together on a single platform even if they are far apart.

\section{References}

[1] United Nations Conference on Trade and Development, "unctad.org | Creative Economy Outlook: Trends in international trade in creative industries," United Nations Conference on Trade and Development. https://unctad.org/en/pages/PublicationWebflyer.aspx?publicationid=2328 (accessed Apr. 10, 2020).

[2] B. E. K. I.- BEKRAF, "Data Statistik dan Hasil Survei Ekonomi Kreatif 2016,” Badan Ekonomi Kreatif Indonesia-. https://www.bekraf.go.id/pustaka/page/data-statistik-danhasil-survei-ekonomi-kreatif-2016 (accessed Apr. 10, 2020).

[3] World Conference on Creative Economy, "2019 Friends of Creative Economy Wraps Up | WCCE," World Conference on Creative Economy. https://www.wcce.id/2019/09/03/2019-friends-of-creative-economy-wraps-up/ (accessed Apr. 10, 2020).

[4] H. McGuirk, H. Lenihan, and M. Hart, "Measuring the impact of innovative human capital on small firms' propensity to innovate," Research Policy, vol. 44, no. 4, pp. 965-976, May 2015, doi: 10.1016/j.respol.2014.11.008.

[5] C. Diebolt and R. Hippe, "The long-run impact of human capital on innovation and economic development in the regions of Europe," Applied Economics, vol. 51, no. 5, pp. 542-563, Jan. 2019, doi: 10.1080/00036846.2018.1495820.

[6] C. Boon, R. Eckardt, D. P. Lepak, and P. Boselie, "Integrating strategic human capital and strategic human resource management," The International Journal of Human Resource Management, vol. 29, no. 1, pp. 34-67, Jan. 2018, doi: 10.1080/09585192.2017.1380063. 
[7] J. Nieves and A. Quintana, "Human resource practices and innovation in the hotel industry: The mediating role of human capital," Tourism and Hospitality Research, vol. 18, no. 1, pp. 72-83, Jan. 2018, doi: 10.1177/1467358415624137.

[8] J. Tidd and J. R. Bessant, Managing Innovation: Integrating Technological, Market and Organizational Change, 5th Edition | Wiley. .

[9] Nicholas. C. Wilson and D. Stokes, "Managing creativity and innovation: The challenge for cultural entrepreneurs," Journal of Small Business and Enterprise Development, vol. 12, no. 3, pp. 366-378, Jan. 2005, doi: $10.1108 / 14626000510612286$.

[10] M. Diaz-Fernandez, M. Bornay-Barrachina, and A. Lopez-Cabrales, "HRM practices and innovation performance: a panel-data approach," International Journal of Manpower, vol. 38, no. 3, pp. 354-372, Jan. 2017, doi: 10.1108/IJM-02-2015-0028.

[11] T. N. Garavan, M. Morley, P. Gunnigle, and E. Collins, "Human capital accumulation: the role of human resource development," Journal of European Industrial Training, vol. 25, no. 2/3/4, pp. 48-68, Jan. 2001, doi: 10.1108/EUM0000000005437.

[12] D. Q. Nguyen, "The impact of intellectual capital and knowledge flows on incremental and radical innovation: Empirical findings from a transition economy of Vietnam," Asia-Pacific Journal of Business Administration, vol. 10, no. 2/3, pp. 149-170, Jan. 2018, doi: 10.1108/APJBA-03-2018-0044.

[13] J. F. L. Hong, X. Zhao, and R. S. Snell, "Collaborative-based HRM practices and open innovation: a conceptual review," The International Journal of Human Resource Management, vol. 30, no. 1, pp. 31-62, Jan. 2019, doi: 10.1080/09585192.2018.1511616.

[14] Á. López-Cabrales, J. C. Real, and R. Valle, "Relationships between human resource management practices and organizational learning capability: The mediating role of human capital," Personnel Review, vol. 40, no. 3, pp. 344-363, Jan. 2011, doi: 10.1108/00483481111118658.

[15] U. Sekaran and R. Bougie, Research Methods For Business: A Skill Building Approach, 7th Edition | Wiley, 7th ed. Wiley, 2016.

[16] S. Candra, E. I. Valtin, and R. T. Agustine, "E-Service Quality of Online Transportation in Indonesia: A Preliminary Finding," presented at the 2019 7th International Conference on Cyber and IT Service Management, CITSM 2019, 2019, doi: 10.1109/CITSM47753.2019.8965343.

[17] S. Candra, H. Cahyono, R. A. Wibowo, and T. Sutopo, "Acceptance of the use of social media: Case of linkedin in Indonesian netizen," International Journal of Scientific and Technology Research, vol. 9, no. 1, pp. 1451-1461, 2020.

[18] J. F. Hair, W. C. Black, B. J. Babin, and R. E. Anderson, Multivariate Data Analysis, 7th Edition, 7th ed. 2010.

[19] N. Kock, "Using WarpPLS in E-Collaboration Studies: An Overview of Five Main Analysis Steps," Advancing Collaborative Knowledge Environments: New Trends in ECollaboration, 2012. www.igi-global.com/chapter/using-warppls-collaborationstudies/61191 (accessed Apr. 10, 2020).

[20] K. Laursen and N. J. Foss, "Human Resource Management Practices and Innovation," The Oxford Handbook of Innovation Management, Jan. 01, 2014. https://www.oxfordhandbooks.com/view/10.1093/oxfordhb/9780199694945.001.0001/ oxfordhb-9780199694945-e-009 (accessed Apr. 10, 2020). 
[21] R. M. Mariz-Perez, M. M. Teijeiro-Alvarez, and M. T. Garcìa-Alvarez, "The relevance of human capital as a driver for innovation," Cuadernos de Economía, vol. 35, no. 98, pp. 68-76, May 2012, doi: 10.1016/S0210-0266(12)70024-9. 